
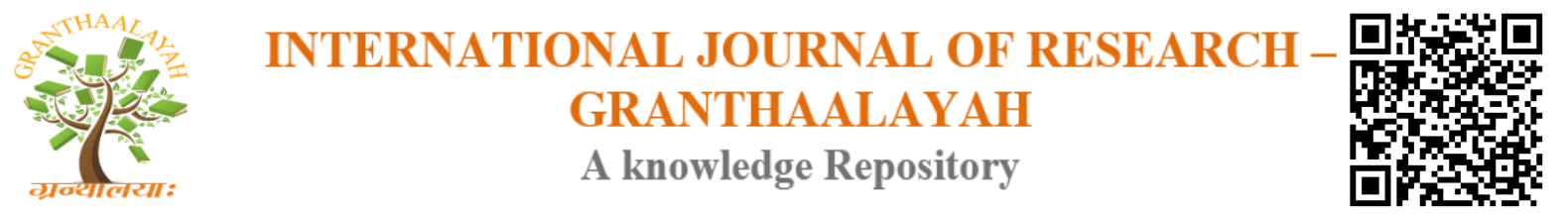

Science

\title{
A SHORT REVIEW ON UNNMAD W.S.R. TO ATTENTION DEFICIT HYPERACTIVITY DISORDER (ADHD)
}

\author{
Dr. Ganesh S Chavan ${ }^{1}$, Dr. Renu B Rathi ${ }^{2}$ \\ ${ }^{1}$ M.D. Kaumarbhritya-Balrog (Ayurved), PG scholar, Kaumarbhritya department, Mahatma \\ Gandhi Ayurvedic Medical College \& Research Centre, Wardha, India \\ ${ }^{2}$ M.D. Kaumarbhritya-Balrog (Ayurved), HOD and Professor, Kaumarbhritya department, \\ Mahatma Gandhi Ayurvedic Medical College \& Research Centre, Wardha, India
}

\begin{abstract}
Unnmad is one type of mansik-vyadhi which is most common form of mental disorder. Unnmad can be co -related with Attention deficit hyperactivity disorder (ADHD). Today's modern era day to day psychosomatic disorder affected children are increased in pediatric clinics, out of that Attention deficit hyperactivity disorder (ADHD) one of them. Due to increased distractibility and difficulty sustaining attention; poor impulse control and decreased self-inhibitory capacity; and motor over activity and motor restlessness. etc leads to this disease.

Attention Deficit Hyperactivity Disorder (ADHD) neurobehavioral disorder of childhood and one of among the most prevalent chronic health conditions affecting school-age children. In modern medicine except presynaptic dopaminergic agonists, there is no other treatment for this disease While traditional life science Ayurveda has most effective solution over this. The present article is an attempt to highlighting on details of unnmada with co-relating with ADHD.
\end{abstract}

Keywords: Unnmad; Attention Deficit Hyperactivity Disorder (ADHD); Treatment; Review.

Cite This Article: Dr. Ganesh S Chavan, and Dr. Renu B Rathi. (2019). "A SHORT REVIEW ON UNNMAD W.S.R. TO ATTENTION DEFICIT HYPERACTIVITY DISORDER (ADHD).” International Journal of Research - Granthaalayah, 7(1), 25-33. https://doi.org/10.29121/granthaalayah.v7.i1.2019.1029.

\section{Introduction}

All the psychiatric diseases in Ayurveda have been described under the heading of 'manasvyadhi'." unnmadam punah mano buddhi sadnya dhyan smruti mati bhakti shil chesta acharvibhram vidhyat" it's the one line unique identity of unnmada. ${ }^{(1)}$ due to etiology of vitiation dhee, dhriti and smriti that causes imbalance of kala and karma which results into improper contact of the senses with their objectives (Asatmendriyartha samyoga) and give rise to inattention, hyperactivity and impulsivity ${ }^{(2)}$. The Prevalence rate of ADHD among primary school children was found to be $11.32 \%{ }^{(3)}$. The ADHD subtype is rare (about $2 \%$ ), while the ADHD subt ype is the predominant one and is associated with severe impairment. There is no satisfactory 
treatment in any other system of medicine except in Ayurveda, where a lot of description about its etiopathogenesis and treatment is available right from the Vedic and Samhita period. Hence it is necessary to study this disease thoroughly.

\section{Definition of Unnmad}

According to Acharya Charak Unnmad, is the manasvyadhi is which understood as the unsettled condition of the Manas (mind), Buddhi (understanding), Samjna (consciousness), Gnana (perception), Smriti (memory), Bhakti (inclination), Sheela (character), Chesta (behaviour), and Achara (conduct) $^{(4)}$.

\section{Nidan Panchaka of Unnmad}

Nidan: the hetu of the Unnmad are given as -

\section{General hetu of Unnmad (5)}

1) Aaharaja Hetu

2) Viharaja Hetu

- Aaharaja-Hetu: Incompatible, dirty, impure food like fruits and milk, heavy diet like nonveg, dhadhi, bekari products etc increases tridoshas

- Viharaja-Hetu: disrespect of Dev (God), Guru (Teachers), Brahmins (learned), excessive bhaya (fear), Harsha (joy) to produce manobhighata disturbing all the normal mental functions increases rajas and tamas mansik doshas. Agantu Unmaadas arising Himsa (cruelty) the Rati (lust) and Abhyarchana (extortion) ${ }^{(6)}$.

\section{Types ${ }^{(7)}$}

classification of Unmaada is based on the prognosis, the knowledge of which is very essential in treating any disease is Focusing on aetiology, mode of manifestation, prognosis and principles of treatment he offers two more classifications as

Nija and Agantu Nija Unmada is further divided into four kinds. They are also known as Doshaja Unmaadas (those arising from the morbidity of Doshas. Out of these the fourth kind namely Sannipataja unmaada. (insanity of tridiscordance) is said to be incurable

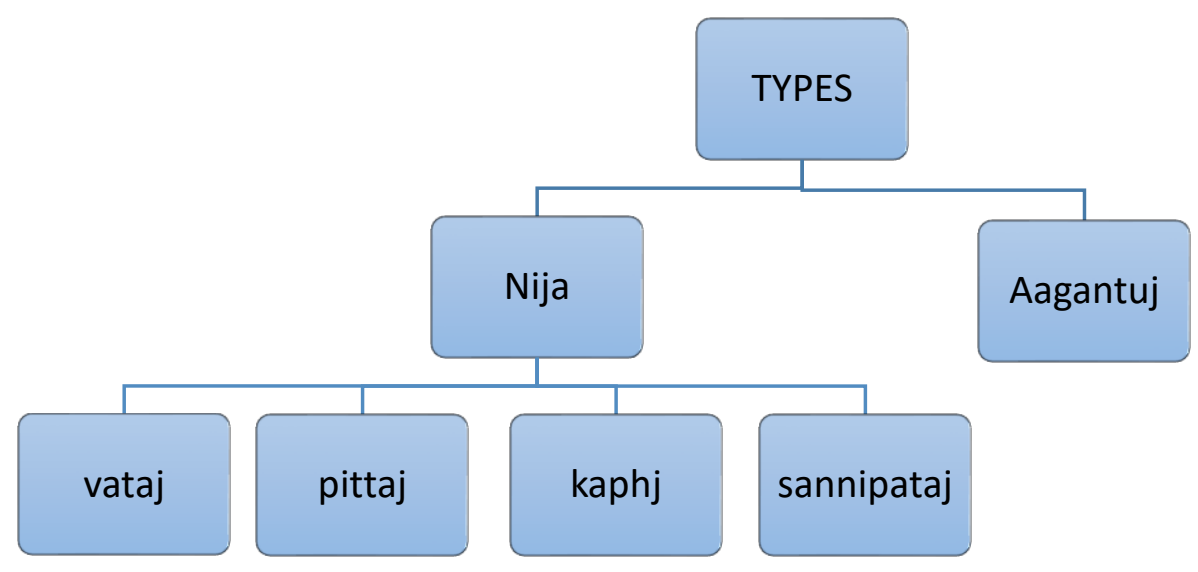


According to Acharya shushruta and vagbhata there are 6 types of unnmad manas unnmad inciuded in this. ${ }^{(8,9)}$

Samprapti (Pathogenesis) $)^{(10)}$

Acharyas have described the following Samprapati of the disease.

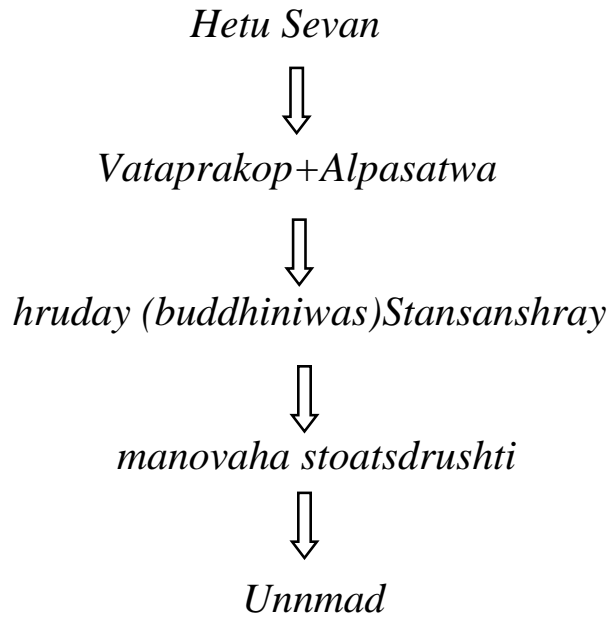

Table 1 : Showing Samprapti-Ghatakas of Unnmad:

\begin{tabular}{|c|c|}
\hline \multicolumn{2}{|c|}{ Samprapti Ghatakas of Unnmad } \\
\hline Doshas & $\begin{array}{c}\text { Sharirik -Tridosha } \\
\text { Mansik- rajas,tamas }\end{array}$ \\
\hline Dushya & Mana \\
\hline Agni & Jatharagnimandya \\
\hline Srotas & Manovaha strotas \\
\hline Srotodusti Prakara & Sanga \\
\hline Udbhavasthana & Hridaya \\
\hline Adhisthana & Mana,indriya, buddhi \\
\hline Vyadhimarga & Madhyam \\
\hline
\end{tabular}

Rupa $^{(11,12)}$

Rupa of unnmad, according to different Ayurvedic classics areas -

Dhi vibrama

satwa pariplawa

drushti adhirata

abaddh vakya

hruday shunyata 
According to different types of dosha involvement the symptoms should be given below

\begin{tabular}{|c|c|c|c|c|}
\hline Vataj & pittaj & kaphaj & sannipataj & aagantuj \\
\hline $\begin{array}{l}\text { astanhas, smit } \\
\text { nrutya, gayan, } \\
\text { radan } \\
\text { (inopportune } \\
\text { laughing, smiling, } \\
\text { dancing, singing, } \\
\text { speaking, } \\
\text { movement of body) }\end{array}$ & $\begin{array}{l}\text { amarsha } \\
\text { (intolerance) }\end{array}$ & $\begin{array}{l}\text { strikamata (desire } \\
\text { to sex) }\end{array}$ & & $\begin{array}{l}\text { sarambha } \\
\text { (agitation) }\end{array}$ \\
\hline $\begin{array}{l}\text { fenagamsyat } \\
\text { (foaming through } \\
\text { mouth) }\end{array}$ & $\begin{array}{l}\text { sarambha } \\
\text { (agitation) }\end{array}$ & $\begin{array}{l}\text { lalashikan } \\
\text { stravam (extra } \\
\text { secreation through } \\
\text { mouth and nose) }\end{array}$ & & $\begin{array}{l}\text { maithuni bhave } \\
\text { rajaswala (sex } \\
\text { during menses sunya } \\
\text { gruh vase } \\
\text { (live alone) }\end{array}$ \\
\hline $\begin{array}{l}\text { yanamatanee } \\
\text { (moving on non- } \\
\text { vehicles) }\end{array}$ & $\begin{array}{l}\text { satarjan } \\
\text { (terrorizing) }\end{array}$ & $\begin{array}{l}\text { Anannabhilasha } \\
\text { (anorexia) }\end{array}$ & $\begin{array}{l}\text { showing } \\
\text { symptoms }\end{array}$ & $\begin{array}{l}\text { sunya gruh vase } \\
\text { (live alone) }\end{array}$ \\
\hline $\begin{array}{l}\text { bahubhashita } \\
\text { (irrilivant } \\
\text { talking) }\end{array}$ & $\begin{array}{l}\text { nagnata } \\
\text { (nakedness) }\end{array}$ & $\begin{array}{l}\text { alpa chakraman } \\
\text { (slow movements) }\end{array}$ & $\begin{array}{c}\text { of } \\
\text { all } \\
\text { doshas }\end{array}$ & $\begin{array}{l}\text { nagnatwa } \\
\text { (nakedness) }\end{array}$ \\
\hline $\begin{array}{l}\text { parushya } \\
\text { (emaciation) }\end{array}$ & krodh(anger) & $\begin{array}{l}\text { ekant priyata } \\
\text { (loving to live } \\
\text { alone) }\end{array}$ & & $\begin{array}{l}\text { discrespect of Dev, } \\
\text { Guru, Brahmins }\end{array}$ \\
\hline $\begin{array}{l}\text { karshya } \\
\text { (lean and thin) }\end{array}$ & $\begin{array}{l}\text { atidravan } \\
\text { (excessive } \\
\text { movement) } \\
\text { excessive } \\
\text { movement } \\
\end{array}$ & $\begin{array}{l}\text { nidradhikya } \\
\text { (excessive } \\
\text { sleeping) }\end{array}$ & & $\begin{array}{l}\text { mastilguddyochiste } \\
\text { (eating wasted food) }\end{array}$ \\
\hline $\begin{array}{l}\text { jirnabala } \\
\text { (less immunity) }\end{array}$ & $\begin{array}{l}\text { pitwarnata } \\
\text { (yellowish } \\
\text { lustre) }\end{array}$ & $\begin{array}{l}\text { swet varnata } \\
\text { (whitish body) }\end{array}$ & & \\
\hline
\end{tabular}

\section{Treatment ${ }^{(13)}$}

Remedial measures for the curable 2 types are as follows:

recitation of mantras, wearing of roots and gems, auspicious rites, offerings, gifts, oblations, religious rules, vow, propitiation, fasting, blessings, prostration, visit to religious places etc.

The therapeutic measures for the 3 curable types of insanity are: unction, fomentation, emesis, purgation, non-unctuous and unctuous enema, pacification, snuffing, smoking, fumigation, collyrium, inhalation of herbal juice, blowing (into the nose), massage, paste, bath, after-paste, striking, tying, confinement, frightening, inducing surprise and forgetting, desaturation and bloodletting, proper dietetic regimen according to dosas, and other remedial measures which are contrary to etiological factors. 


\section{Modern Review of ADHD ${ }^{(14)}$}

\section{- Definition}

Attention deficit hyperactivity disorder (ADHD) is a behavioural disorder that includes symptoms such as inattentiveness, hyperactivity and impulsiveness.

\section{- Causes}

The exact cause of attention deficit hyperactivity disorder (ADHD) is not fully understood, although a combination of factors is thought to be responsible.

1) Genetics- ADHD tends to run in families and, in most cases, it's thought the genes you inherit from your parents are a significant factor in developing the condition.

2) Brain function and structure - Studies involving brain scans have suggested that certain areas of the brain may be smaller in people with ADHD, whereas other areas may be larger.

3) Groups at risk-

- who were born prematurely (before the 37th week of pregnancy) or with a low birth weight

- with epilepsy

- with brain damage

\section{Symptoms in Children and Teenagers}

- The symptoms of ADHD in children and teenagers are well defined, and they're usually noticeable before the age of 6 . They occur in more than one situation, such as at home and at school.

\section{Inattentiveness}

The main signs of inattentiveness are:

- having a short attention span and being easily distracted

- making careless mistakes - for example, in schoolwork

- appearing forgetful or losing things

- being unable to stick to tasks that are tedious or time-consuming

- appearing to be unable to listen to or carry out instructions

- constantly changing activity or task

- having difficulty organizing tasks

- having difficulty organising tasks

\section{Hyperactivity and Impulsiveness}

The main signs of hyperactivity and impulsiveness are:

- being unable to sit still, especially in calm or quiet surroundings

- constantly fidgeting

- being unable to concentrate on tasks

- excessive physical movement

- excessive talking

- being unable to wait their turn

- acting without thinking

- interrupting conversations

- little or no sense of danger 
These symptoms can cause significant problems in a child's life, such as underachievement at school, poor social interaction with other children and adults, and problems with discipline.

\section{Medication}

There are 5 types of medication licensed for the treatment of ADHD: methylphenidate dexamfetamine lisdexamfetamine atomoxetine These medications are not a permanent cure for ADHD but may help someone with the condition concentrate better, be less impulsive, feel calmer, and learn and practice new skills.

\section{Ayurvedic Management of ADHD:}

The Ayurvedic treatment of ADHD involves correction or balancing of tarpaka kapha, sadhaka pitta, and prana vayu, the doshas present in the brain.

1) Nootropic herbs: following herbs have possible action on psycho-neurological deficits; Ashwagandha, Brahmi, Shanka pushpi, Jatamansi (Nardostachys Jatamansi, Vacha (Acoruscalamus). These may act as a mild stimulant and sedative also depending on what mood state needs to be balanced.

- Ashwagandha: The use of Ashwagandha in Indian culture for a very long time for all age groups irrespective to sexes and even during pregnancy without any side effects. ${ }^{(15)}$ Clinical trials and animal research support the use of WS for anxiety, cognitive and neurological disorders i.e. Two new glycowithanolides, sitoindoside IX (1) and sitoindoside X (2), isolated from Withania somniferous Dun., were evaluated for their immunomodulatory and CNS effects (anti-stress, memory and learning) in laboratory animals. ${ }^{(16)}$

- Brahmi: It has been traditionally used for its medicinal properties as a neuro-protective and protects the nerves degeneration. It effectively treats depression and epilepsy and it has been observed that Brahmi acts as anti-depressant properties equal to modern antidepressant medicines. ${ }^{(17)}$

- Vacha: The methanol and acetone extract of Acorus calamus leaves was evaluated for their CNS activity in mice. They showed the spontaneous locomotors activity for immobility by time using through forced timed swim test, diazepam induced sleeping time and motor impairment assessment using Rota rod for CNS depression/ analytic activity of ACME and ACAE in mice. ${ }^{(18)}$ The various methods which is used for inducing the experimental epileptic models induces the recurrent seizures and epileptic discharge similar to humans post traumatic epilepsy through generation of free radicals into sensorimotor. ${ }^{(19)}$

- Jatamansi: It has been widely used for medicine and in perfumery for centuries in India. It is valued for many medicinal properties such as anti-lipid per oxidative, antioxidant, sedative, tranquilizing, antihypertensive, antidepressant-like activity, anticonvulsant activity and hypotensive properties and several nervous disorders such as epilepsy, neurosis, insomnia, excitation, alzheimer's disease, learning and memory disorders. ${ }^{(20)}$

- Tinospora cordifolia: It is used as a Rasayana in Ayurveda since vedic period for treating and prevention of many diseases. Previous studies suggests the effect of Tinospora cordifolia on learning and memory in normal rats and on cyclosporine induced memory 
deficits, both alcoholic and aqueous extract of T. cordifolia enhanced the cognition in normal rats as were seen in behavioral tests - Hebb William maze and the passive avoidance task. ${ }^{(21)}$

2) Panchakarma - Abhayanga, Shirodhara and Shiro Pichhu.

- Abhayang (oleationtherapy): Abhyanga is the process of application of plain / medicated oil or Sneha Dravya over the body with massage. ${ }^{(22)}$ Snehana therapy is useful for promoting strength, nourishment (bulk), vitality (energy) to the deficient part and particular required area of the body. The abhayanga with medicated oils i.e. Chandanaaadhi, Mahanarayana and Bala are provides stimulation to the nervous system improves the sensory motor integration.

- Shirodhara: Shirodhara is a type of Murdha taila $^{(23)}$ (Application of oil to the head/ scalp) in which prescribed medicated oil/ liquid is continuously poured over the forehead and then allowed to flow over the scalp from a specific height for a certain period of time. Mahanarayana and Bala are more effective in treating patients of ADHD by lipophilic and hydrophilic active principles of Vatavyadhinashaka (Vata normalizing) drugs, which may modulate the secretions of various neurotransmitters and hormones in brain. Constant flow of liquid use in Shirodhara act as relax the mind, calms \& tranquilizer the patients. ${ }^{(24)}$

3) Behavioral therapy (SatvaAvajayachikitsa): Sattvavajaya Chikitsa of ADHD is the commonest neuro-bherival disorders in pediatrics age group, so some protocols adopted for treating these type of patients i.e.

- Counseling to the parents, family members, teachers and child itself is of great help in treating as well as prevention of ADHD patients.

- The use of medicines which have properties of cognitive function along with Meditation or Yoga.

- It is assisted with the daily diet regulation and making sleep time-table of an affected child. Diet should be of nutritional balance, on proper time, avoiding excess oil and spice, rich in antioxidants and immunity boosters.

- Sound sleep and a good amount of water intake is also a must.

- Scalp massage (Shiro abhyanga), massage of soles of feet with sesame oil is also beneficial in decreased hyperactive.

- Daily work should be listed and overcoming problems (e.g. during writing) should be handled one by one and slowly.

- Daily use of Cow's ghee, cod-liver oil, are playing good role to develop brain activities and prevent developing of ADHD.

- The previous studies have been shown the nootropic effect of some herbal medications which play a major role in treating as well as prevention of ADHD, such as:

\section{4) Dietary Management}

Most of ADHD affected patients have the proper nutrients deficient that's why, parents who are troubled with medicating their children are often more comfortable with the initiative of dietary interventions. ${ }^{(25)}$ Proper nutrition is essential for growing children, and children who eat a diet high in "junk food" in early childhood are more likely to exhibit hyperactivity by age seven; this may reflect a long-term nutritional imbalance. ${ }^{(26)}$ So advised the parents to refined, carbohydrates, 
sugars, and processed foods containing additives should be completely eliminated from the diet.

\section{Conclusion}

Psychiatric disorder is well explained in Ayurvedic samhita. That ancient knowledge of Ayurveda will helps in diagnosis and management unnmad in present era very well. In Ayurveda it may be correlated to Unmad (insanity) disease which is Vatika Vikara. So, line of treatment according to Vatika disorders such as neuro-protactive medications along with Pancha karma therapies have definitely shown outcome on the disease and thus pave way to further researches in employing Ayurvedic methods towards the management of $A D H D$.so its review article is an attempt to highlighting on details unnmada with co-relating with ADHD.

\section{References}

[1] Dr. Brahmanada Tripathi, Charak Samhita of Maharshicharak, Chukhambhaprakashan, Varanasi, 2010, nidansastan, chapter 7, verse no.5, page no.640

[2] Dr. Brahmanada Tripathi, Charak Samhita of Maharshicharak, Chukhambhaprakashan, Varanasi, 2010, Sharir sthana,, chapter 1, verse no102,page no.822

[3] https://www.ncbi.nlm.nih.gov.article (22 nov.2018: $12.30 \mathrm{am}$ )

[4] Dr. BrahmanadaTripathi, Charak Samhita of Maharshicharak, Chukhambhaprakashan, Varanasi, 2010, nidansastan, chapter 7, verse no.5, page no.640.

[5] Dr. BrahmanadaTripathi, Charak Samhita of Maharshicharak, Chukhambhaprakashan, Varanasi, 2010, nidansastan, chapter 7, verse no.4, page no.640

[6] Astanga hryadium of vagbhata text, English translation, notes, Indeces etc translated byProf. K.R. Srikantha Murthy @ Chaukhamba orientalia, edition,2002; Uttertantra chapter no. 6 verse no.6-10

[7] Dr.BrahmanadaTripathi, Charak Samhita of Maharshicharak, Chukhambhaprakashan, Varanasi, 2010, nidansastan, chapter 7, verse no.3, page no.639.

[8] Sushrutasamhita by Dr.Anant ram Sharma foreword by Acharya priyavat Sharma chaukhmasurbhartiprakashan ,uttartantra,chapter no.62 verse no.4.page no.504.

[9] Astanga hryadium of vagbhata text, English translation, notes, Indeces etc translated byProf. K.R. Srikantha Murthy @ Chaukhamba orientalia, edition, 2002; uttartantra chapter no.6, verse no.1

[10] Dr.BrahmanadaTripathi, Charak Samhita of Maharshicharak, Chukhambhaprakashan, Varanasi, 2010, nidansastan, chapter 7, verse no.4,page no.640.

[11] Dr.BrahmanadaTripathi, Charak Samhita of Maharshicharak, Chukhambhaprakashan, Varanasi, 2011, Chikitsastan, chapter 9, verse no.6 page no.376.

[12] Madhavnidan by Dr. Ajay kumar an Android book, chapter no.67 verse no.20/4

[13] Charak samhita -Handbook on ayurveda vol 2 Edited by Gabriel Van Loon Chaukhambha Orientalia Publishers 2002 page no.1107-1108

[14] https://www.nhs.uk/.../symptoms (22 nov.2018: $12.30 \mathrm{am)}$

[15] S. Sharma, S. Dahanukar, S.M. Karandikar. Effects of long-term administration of the roots of ashwagandha and shatavari in rats. Indian Drugs, 1985; 29: 133-139.

[16] Immunomodulatory and CNS effects of Sitoindosides IX and X, Two New Glycowithanolides from Withania somnifera. Shibnath Ghosal, Jawahar Lal and Radheyshayam Srivastava Phytotherapy Research, 1989; 3: 5.

[17] The pharmacology of bacopa monneri -A review by dept of pharmacology, nasiriyah published in international journal of pharma sciences and research (IJPSR).

[18] Pandy, V., N. Jose and H. Subhash, CNS activity of methanol and acetone extract of Acorus calamus leaves in mice, J. Pharmacol. Toxicol, 2009; 4(2): 79-86. 
[19] Pradhan, S.N., K. Ray, R. Hazra and R.D. Ghua, Inhibitory role of Acorus calamus in ferric chloride induced epileptogenesis in rat, Hum. Exp. Toxicol., 2007; 27(12): 947953.

[20] Nardostachys jatamansi improves learning and memory in mice. Journal of Medicinal Food, 9(1): 113-8.

[21] Agarwal A, Malini S, Bairy KL, Rao MS. Effect of Tinosporacordifoliaon learning and memory deficitrats. Ind. Journal of Pharmacol, 2002; 34(5): 339-49.

[22] . Astanga hryadium of vagbhata text, English translation, notes, Indeces etc translated byProf. K.R. Srikantha Murthy @ Chaukhamba orientalia, edition, Sutur stan, 2002; 2: 8-9.

[23] Astanga hryadium of vagbhata text, English translation, notes, Indeces etc translated by Prof. K.R. Srikantha Murthy@ Chaukhamba orientalia, edition, Sutur sthsn, 2002; 22/2.

[24] A practical handbook of Panchakarma procedures, Chief editer Prof. G.S. Liavekar Director General of CCRAS, New Delhi, 62.

[25] Nigg JT. What Causes ADHD? New York, NY: The Guilford Press, 2006.

[26] Wiles NJ, Northstone K, Emmett P, Lewis G. „Junk food diet and childhood behavioural problems: results from the ALSPAC cohort. Eur J Clin Nutr, 2009; 63: page no.491-98.

\footnotetext{
*Corresponding author.

E-mail address: gc4538@gmail.com/rbr.226@gmail.com
} 